\title{
A NEW SPECIES OF THE GENUS CHONDROSTOMA AGASSIZ, 1832 (ACTINOPTERYGII, CYPRINIDAE) FROM THE IBERIAN PENINSULA
}

\author{
I. Doadrio* and J. A. Carmona*
}

\begin{abstract}
A new species considered in the past to be included in Chodrostoma lemmingii is described on the basis of genetic and morphological characters. This new species inhabits tributaries of the Jándula River in the Guadalquivir basin, in southern Spain. It is distinguished from $C$. lemmingii by the following: 1) six to seven branched rays on the dorsal and anal fins, 2) a relatively small number of gill rakers $(x=25.4), 3)$ a large eye placed very anterior on the head, 4) a high and narrow coronoid process on the dentary, 5) the palatine process of the maxilla posteriorly oriented and, 6) the presence of a diagnostic locus $(M D H-A)$. The range of Chondrostoma oretanum sp. nov. is restricted to the Robledillo and Fresneda Rivers, two small tributaries of the Jándula River in the Guadalquivir basin on the Atlantic slope of the Iberian Peninsula. Following the criteria established by IUCN Red List Categories, we consider $C$. oretanum to be critically endangered (CR B1 + 2ce).
\end{abstract}

Key words: Cypriniformes, Cyprinidae, Taxonomy, Chondrostoma oretanum, Jándula River.

\section{RESUMEN}

Una nueva especie de el género Chondrostoma Agassiz, 1832 (Actinopterygii, Cyprinidae) de la Península Ibérica

Se describe una nueva especie considerada hasta ahora una población de Chondrostoma lemmingii en base a caracteres genéticos y morfológicos. La nueva especie del género Chondrostoma procede de algunos afluentes del río Jándula en la cuenca del Guadalquivir, sur de España. Esta nueva especie se diferencia de $C$. lemmingii por presentar de seis a siete radios ramificados en las aletas dorsal y anal, un número bajo de branquiespinas $(x=25.4)$, los ojos grandes y situados muy anteriormente en la cabeza, proceso coronoideo del dentario alto y estrecho, proceso palatino del maxilar orientado hacia atrás y presencia de un locus diagnóstico $(M D H-A)$. La distribución de Chondrostoma oretanum sp. nov. se restringe a los ríos Robledillo y Fresneda, dos pequeños afluentes del río Jándula en la cuenca del Guadalquivir, situada en la vertiente Atlántica de la Península Ibérica. La nueva especie debería considearse. Siguiendo los criterios de las categorías de la Lista Roja de la IUCN, nosotros consideramos a $C$. oretanum como En Peligro Crítico (CR B1 + 2ce).

Palabras clave: Cipriniformes, Cyprinidae Taxonomía, Chondrostoma oretanum, Río Jándula.

* Museo Nacional de Ciencias Naturales. José Gutiérrez Abascal 2. 28006 Madrid. Spain. mcnd147@mncn.csic.es 


\section{Introduction}

The Iberian Peninsula is home to a great variety of freshwater fishes, including several endemic groups. Cyprinids make up the most diverse group of these freshwater fishes.

In the Iberian Peninsula cyprinids comprise approximately 27 native species (Doadrio, 2001). Ten of these, all endemic, belong to the genus Chondrostoma Agassiz, 1832 (sensu Zardoya \& Doadrio, 1998). The high level diversity within this genus seems to have resulted from both vicariant events during the regression of the Sarmatic Sea in the late Miocene, and by the formation of the present-day drainage system during the Pliocene (Zardoya \& Doadrio, 1999).

Morphologically, the genus Chondrostoma on the Iberian Peninsula can be divided into two different groups of "large" and "small" species. The "large species" group includes C. arrigonis (Steindachner, 1866), C. duriense Coelho, 1985, C. miegii Steindachner, 1866, C. polylepis Steindachner, 1864, $C$. turiense Elvira, 1987 and C. willkommii Steindachner, 1866 whilst the "small species" group contains C. arcasii (Steindachner, 1866), C. lemmingii (Steindachner, 1866), C. lusitanicum Collares-Pereira, 1980 and C. macrolepidotum (Steindachner, 1866).

Favoured by its size, the "large species" group shows upstream reproductive dispersal patterns that can be presumed to be migratory movements within the basin (Doadrio, 2001). Due to its dispersal capacity, we hypothesize that the species of this group have a low population structure. In contrast, the "small species" group shows no reproductive dispersal pattern and their ability to colonize new areas is limited by morphological and ecological features. Therefore, we believe species within this group to be characterised by a high population structure.

Chondrostoma lemmingii is a member of the "small species" group that inhabit the south-western basins of the Iberian Peninsula. In recent genetic studies, a high level of genetic divergence has been observed in the populations of $C$. lemmingii from the Duero and Guadalquivir basins (Carmona et al., 2000). The Duero population, recently described as a new species (Doadrio \& Elvira, in press), is thought to have started its differentiation during the Messinian period (6 MYA) (Carmona et al., 2000). On the basis of genetic characters, the differentiation process of the population from the Robledillo River (Guadalquivir basin) was estimated to have begun during the middle Pliocene (3 MYA) (Carmona et al., 2000).
The genetic differentiation observed in the Duero and Robledillo River for these C. lemmingii populations (Carmona et al., 2000) was similar to that observed by Casado (1995) in her morphometric study (Casado, 1995) of the same populations.

The purpose of this study was to describe the specimens from the Robledillo \& Fresneda Rivers as a new species of the genus Chondrostoma. Although this species had been previously defined through morphological and genetic analysis, it was, until this present study, undescribed.

\section{Materials and Methods}

The description of this new Chondrostoma species is based on twenty adult males and nine adult females. The holotype and a series of paratypes have been deposited in the Museo Nacional de Ciencias Naturales (Spain). Twenty-three morphometric variables were measured. All measurements are in millimetres and were log-transformed for morphometric analysis.

The following abbreviations were used for morphometric and meristic characters: SL, standard length; HL, head length; PrOL, preorbital length; ED, eye diameter; PrDD, predorsal distance; PrPD, prepectoral distance; PrVD, preventral distance; PrAD, preanal distance; CPL, caudal peduncle length; APL, anal peduncle length; PVL, pectoralventral length; VAL, ventral-anal length; DFL, dorsal fin length; DFH, dorsal fin height; PFL, pectoral fin length; VFL, ventral fin length; AFL, anal fin length; AFH, anal fin height; CFL, caudal fin length; BD body depth; BLD, body least depth; LLS, lateral line scales rows; SRA, scale rows above lateral line; SRB, scale rows below lateral line; GR, gill rakers; $\mathrm{D}$, dorsal fin rays; A, anal fin rays; $\mathrm{P}$, pectoral fin rays; $\mathrm{V}$, ventral fin rays; $\mathrm{C}$, caudal fin rays. Only branched fins rays were counted. The osteological characters were studied from clear and stained specimens (Wassersug, 1976). Institutional acronyms: MNCN Museo Nacional de Ciencias Naturales; NMW Naturhistorischen Museum Wien.

\section{Chondrostoma oretanum sp. nov.}

Holotype: (Fig. 1, Table 1). MNCN 50739 Male, $78.85 \mathrm{~mm}$ SL. Robledillo River, La Solana del Pino, Ciudad Real. Guadalquivir basin, Spain. Leg. Ignacio Doadrio. 20.V.1989.

PARATYPES: (Table 1, 2) MNCN 50735-38; MNCN 50740-45, 10 individuals. Robledillo River, La Solana del Pino, Ciudad Real. Guadalquivir basin, Spain. Leg. Ignacio Doadrio. 


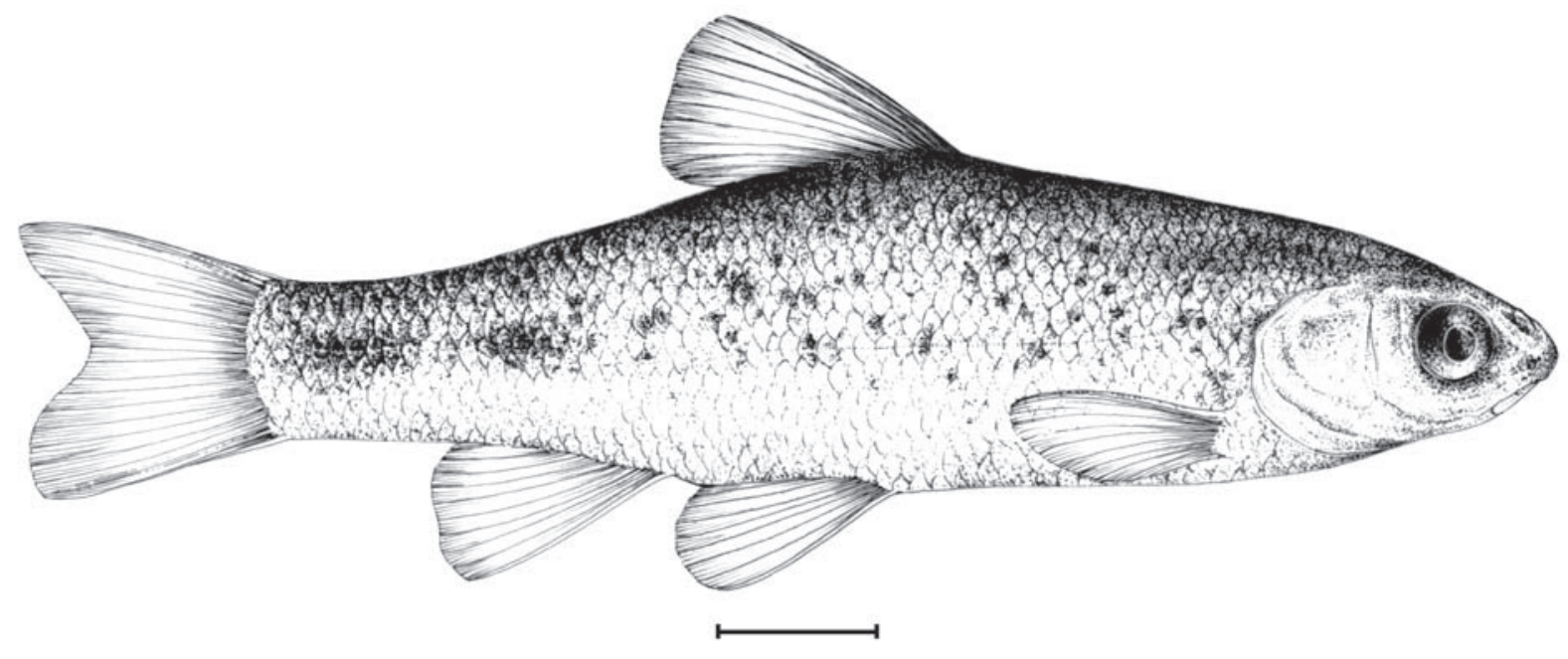

Fig. 1.-Chondrostoma oretanum sp. nov. Holotype, male, MNCN 50739. Robledillo River, La Solana del Pino, Ciudad Real. Spain.

Fig. 1.- Chondrostoma oretanum sp. nov. Holotipo, macho, MNCN 50739. Río Robledillo, La Solana del Pino, Ciudad Real. España.

20.V.1989. MNCN 117490-507, 18 individuals. Robledillo River, La Solana del Pino, Ciudad Real. Guadalquivir basin, Spain. Leg. J. A. González Carmona. 19.X.1994.

COMPARATIVE MATERIAL: Chondrostoma arcasii: NMW 50646: 1-5. 5 individuals. Syntypes. Queiles River, Tudela, Navarra. Ebro basin, Spain. Leg. F. Steindachner. 1865. Chondrostoma lemmingii: MNCN 29035-7. 3 individuals. Alburrel River, Valencia de Alcantara, Cáceres. Tajo basin, Spain. Leg. Ignacio Doadrio. 12.V.1985. MNCN 29718-38. 21 individuals. Salor River, Cáceres. Tajo basin, Spain. VIII.1930. MNCN 29015-34 30 individuals. Aljucén River, Aljucén, Badajoz. Guadiana basin. VIII-1930. MNCN 29739-68. 30 individuals. Ortigas River, Magacela, Badajoz. Guadiana basin, Spain. 29.XII.1984. 30 individuals. Quejigares River, Fontanosas, Ciudad Real. Guadiana basin, Spain. Leg. I. Doadrio. 6.VIII.1984. MNCN 29367-73. 6 individuals. Cascabalero River, Villanueva de las Cruces, Huelva. Odiel basin, Spain. Leg. I. Doadrio. 12.IV.1979. MNCN 29246-74. 29 individuals. Bembezar River, Azuaga, Badajoz. Guadalquivir basin, Spain. Leg. I. Doadrio. 28.XII.1984. NMW 52373:1,2; 52366, 52357. 4 individuals. Syntypes. Mérida, Badajoz. Guadiana basin, Spain. Leg. F. Steindachner. XII.1864. Chondrostoma macrolepidotum: NMW 498154 individuals. (3 ex. are Syntypes). Alcobazar and Cintra, Portugal. Leg. F. Steindachner. XII.1864.

DiAGNOSIS: Differs from all other known species of Chondrostoma by the following combination of characters: six to seven branched rays in the dorsal and anal fins. Six pharyngeal teeth on the left side and five on the right. Eye diameter longer than preorbital distance. Number of gill rakers $\bar{x}=25.4$ (range: 24-27). High and narrow coronoid process on the dentary. The palatine process of the maxilla posteriorly oriented. Presence of one diagnostic locus $(M D H-A)$.

Etymology: The species name "oretanum" derives from the old Oretania, an area in South-central Spain that was formerly inhabited by the Oretano people. The range of this species coincides with this area.

COMMON NAMES: pardilla oretana, pardilla del Jándula.

Description: D II-III 6-7, A II-III (6-7), P I 12, V I 7, C 19, LLS $\bar{x}=57.1(55-60)$, SRA $\bar{x}=11.4$ $(11-12), \mathrm{SRB} x=5.8(5-6)$, GR $x=25.4(24-27)$. Abdominal vertebrae 19-20, caudal vertebrae 1718. Body of Chondrostoma oretanum sp. nov. is more elongated body than that of $C$. lemmingii. Morphometric characters are given in Tables $(1,2)$. Minimal body depth is 4.9-3.7 (4.3) times in the caudal peduncle. Minimum body depth is 2.9-2 (2.5) times in the anal peduncle. Maximum body depth is 5.4-4.2 (4.8) times in the standard length. Short head, comprising 4.5-4.2 (3.8) times the standard length. Eye placed anterior on the head, its diameter is proportionally bigger than in C. lemmingii. Preorbital distance shorter than eye diameter, reaching 1.5-1 (1.2) times the eye diameter (Table 3). Ventral fin is inserted at or before the origin of the dorsal fin, on the same axis. Preventral length is 1-1.1 (1) times the predorsal length. Fin 
Table 1.- Statistical parameters for the morphometric and meristic characters of $C$. oretanum sp. nov. type series. Variables are described in Methods. (SD = Standard deviation).

Tabla 1.- Parámetros estadísticos para los caracteres morfométricos y merísticos de la serie tipo de C. oretanum sp. nov. Las variables se describen en la metodología. ( $\mathrm{SD}=$ desviación estándar).

\begin{tabular}{|c|c|c|c|c|c|c|c|}
\hline \multirow[b]{3}{*}{ Variable } & \multicolumn{7}{|c|}{ C. oretanum sp. nov. } \\
\hline & \multicolumn{4}{|c|}{ Males $(n=19)$} & \multicolumn{3}{|c|}{ Females $(n=9)$} \\
\hline & Holotype & Range & Mean & $\mathrm{SD}$ & Range & Mean & SD \\
\hline SL & 78,85 & $85,55-45,75$ & 65,21 & 8,05 & $89,89-60,78$ & 68,32 & 5,34 \\
\hline HL & 20,79 & $20,79-11,7$ & 15,77 & 1,67 & $21,59-13,59$ & 15,82 & 1,53 \\
\hline PrOL & 4,59 & $5,1-2,84$ & 3,78 & 0,36 & $5,58-3,11$ & 3,73 & 0,42 \\
\hline ED & 5,87 & $5,52-3,67$ & 4,59 & 0,52 & $5,62-4,09$ & 4,67 & 0,32 \\
\hline PrDD & 42,99 & $43,36-24,96$ & 33,70 & 3,58 & $48,37-32,59$ & 35,51 & 3,22 \\
\hline PrPD & 19,68 & $21,45-12,57$ & 16,47 & 1,65 & $22,33-14,94$ & 16,60 & 1,56 \\
\hline PRVD & 40,02 & $39,96-23,47$ & 32,40 & 3,42 & $44,57-31,46$ & 34,51 & 2,63 \\
\hline PrAD & 54,61 & $59,01-31,9$ & 44,57 & 5,28 & $59,43-43,38$ & 47,07 & 3,19 \\
\hline CPL & 32,95 & $36,95-16,68$ & 26,03 & 3,87 & $35,93-24,51$ & 27,18 & 2,23 \\
\hline APL & 18,7 & $20,59-10,41$ & 15,04 & 1,97 & $18,47-13,34$ & 15,46 & 1,23 \\
\hline PVL & 18,38 & $21,96-9,67$ & 15,52 & 2,24 & $22,56-16,13$ & 17,89 & 1,41 \\
\hline VAL & 14,03 & $15,08-6,17$ & 11,19 & 1,55 & $15,71-9,63$ & 12,23 & 1,51 \\
\hline DFL & 8,77 & $9,57-5,04$ & 7,26 & 0,98 & $8,68-4,52$ & 6,69 & 0,86 \\
\hline DFH & 16,11 & $17,31-9,3$ & 13,59 & 1,70 & $17,97-10,1$ & 14,05 & 1,28 \\
\hline PFL & 16,43 & $16,43-10,49$ & 13,05 & 1,34 & $14,58-10,69$ & 12,49 & 0,78 \\
\hline VFL & 14,68 & $14,68-8,51$ & 11,63 & 1,32 & $14,33-8,97$ & 10,32 & 1,00 \\
\hline AFL & 8,26 & $8,72-4,44$ & 6,32 & 0,86 & $8,69-5,29$ & 6,44 & 0,66 \\
\hline $\mathrm{AFH}$ & 12,85 & $14,05-8,62$ & 11,82 & 1,44 & $16,53-10,17$ & 11,58 & 1,17 \\
\hline CFL & 15,13 & $15,55-11,15$ & 13,06 & 1,31 & $16,56-13,53$ & 15,05 & 1,52 \\
\hline $\mathrm{BD}$ & 18,76 & $18,76-9,45$ & 13,62 & 1,89 & $21,64-12,35$ & 14,21 & 1,65 \\
\hline BLD & 9 & $9-4,26$ & 6,17 & 0,98 & $9,37-5,37$ & 6,24 & 0,72 \\
\hline $\mathrm{D}$ & 6 & $7-6$ & 6,58 & 0,50 & $7-6$ & 6,44 & 0,49 \\
\hline A & 7 & $7-6$ & 6,68 & 0,42 & $7-6$ & 6,44 & 0,49 \\
\hline
\end{tabular}

A


Fig. 2.- Osteological characters. 1, dentary bone; 2, maxilla; 3, cleithrum. A: C. oretanum sp. nov. B: C. lemmingii.

Fig. 2.- Caracteres osteológicos. 1, dentario; 2, maxilar; cleitro. A: C. oretanum sp. nov. B: C. lemmingii.

B size moderately large. Dorsal and pectoral fins are approximately the same size $(\mathrm{DFH} / \mathrm{PFL}=1 \quad 1.3-0.8)$ and slightly shorter than head length.

Osteology: (Fig. 2): High and narrow coronoid process on the dentary. The palatine process of the maxilla posteriorly oriented. The posterior branch of cleithrum is straight and narrow.

PigMENTATION PATTERN: Body brown and green, darkly spotted above the lateral line. Black pigmented scales, a rarity, on the lateral line. Below the lateral line body is light brown. Peritoneum is black. All fins with dark spots.

SEXUAL DIMORPHISM: Males have proportionally larger ventral fins.

Distribution: Populations of $C$. oretanum sp. nov. are scarce and are restricted to the Robledillo and Fresneda Rivers, two small tributaries of the Jándula River in the Guadalquivir basin (Fig. 3). The Jándula River is the only known locality of another endemic cyprinid fish, Squalius palaciosi (see Doadrio, 1980). 
Table 2.- Statistical parameters for the morphometric characters of $C$. oretanum sp. nov. Each variable is divided by standard length. Variables are described in Methods. ( $\mathrm{SD}=$ Standard deviation).

Tabla 2.- Parámetros estadísticos para los caracteres morfométricos de C. oretanum sp. nov. Cada variable está dividida por la longitud estandard. Las variables se describen en la metodología. (SD = desviación estándar).

\begin{tabular}{lcccccc}
\hline & \multicolumn{7}{c}{ C. oretanum sp. nov. } \\
\cline { 2 - 7 } Variable & \multicolumn{3}{c}{ Males $(\mathrm{n}=19)$} & \multicolumn{3}{c}{ Females $(\mathrm{n}=9)$} \\
\cline { 2 - 7 } & Range & Mean & SD & Range & Mean & SD \\
\hline SL & $85,55-45,75$ & 65,21 & 8,052 & $89,89-60,78$ & 68,32 & 0,000 \\
HL/SL & $0,26-0,23$ & 0,24 & 0,010 & $0,24-0,22$ & 0,23 & 0,007 \\
PrOL/SL & $0,07-0,05$ & 0,06 & 0,005 & $0,06-0,05$ & 0,05 & 0,005 \\
ED/SL & $0,08-0,06$ & 0,07 & 0,004 & $0,08-0,06$ & 0,07 & 0,004 \\
PrDD/SL & $0,56-0,49$ & 0,52 & 0,016 & $0,54-0,50$ & 0,52 & 0,014 \\
PrPD/SL & $0,29-0,23$ & 0,25 & 0,014 & $0,25-0,23$ & 0,24 & 0,011 \\
PRVD/SL & $0,53-0,46$ & 0,50 & 0,012 & $0,53-0,49$ & 0,51 & 0,016 \\
PrAD/SL & $0,72-0,65$ & 0,68 & 0,015 & $0,72-0,66$ & 0,69 & 0,013 \\
CPL/SL & $0,45-0,36$ & 0,40 & 0,015 & $0,42-0,39$ & 0,40 & 0,016 \\
APL/SL & $0,25-0,21$ & 0,23 & 0,011 & $0,25-0,21$ & 0,23 & 0,012 \\
PVL/SL & $0,27-0,21$ & 0,24 & 0,020 & $0,28-0,24$ & 0,26 & 0,016 \\
VAL/SL & $0,23-0,13$ & 0,17 & 0,015 & $0,21-0,15$ & 0,18 & 0,020 \\
DFL/SL & $0,14-0,09$ & 0,11 & 0,012 & $0,12-0,07$ & 0,10 & 0,015 \\
DFH/SL & $0,25-0,18$ & 0,21 & 0,016 & $0,23-0,17$ & 0,21 & 0,017 \\
PFL/SL & $0,25-0,17$ & 0,20 & 0,019 & $0,20-0,16$ & 0,18 & 0,016 \\
VFL/SL & $0,20-0,16$ & 0,18 & 0,013 & $0,16-0,14$ & 0,15 & 0,015 \\
AFL/SL & $0,11-0,08$ & 0,10 & 0,008 & $0,11-0,08$ & 0,09 & 0,007 \\
AFH/SL & $0,20-0,16$ & 0,18 & 0,011 & $0,18-0,16$ & 0,17 & 0,009 \\
CFLSL & $0,22-0,16$ & 0,19 & 0,011 & $0,22-0,18$ & 0,20 & 0.008 \\
BD/SL & $0,24-0,19$ & 0,21 & 0,013 & $0,24-0,19$ & 0,21 & 0,014 \\
BLD/SL & $0,11-0,08$ & 0,10 & 0,006 & $0,10-0,08$ & 0,09 & 0,006 \\
\hline
\end{tabular}

REMARKs: C. oretanum sp. nov. inhabits clear waters with sandy to rocky bottoms and prefers slow flowing stretches with abundant aquatic macrophytes and riparian cover. The species occurs in sympatry with Barbus sclateri Günther, 1868 Squalius pyrenaicus (Günther, 1868), Squalius alburnoides (Steindachner, 1866), and with Cobitis paludica de Buen, 1930.

CONSERVATION: The Robledillo and Fresneda Rivers flow through an area of well-preserved Mediterranean forest that is of enormous environmental value. Recently, however, the Public River Administration built a small dam with a hydrologi- cal monitoring station that has had serious impacts on the Robledillo River. In addition, two small reservoirs inhabited by exotic fishes have also severely affected the Fresneda River. The impacts on these rivers have drastically reduced populations and $C$. oretanum sp. nov. Following the criteria established by IUCN Red List Categories, we consider $C$. oretanum to be critically endangered (CR B1 + 2ce).

Comparative DATA AND DISCUSSION: Populations from the Jándula basin diverge to such a high degree from other populations of $C$. lemmingii, both morphologically and genetically (Table 4), that it

Table 3.- Frequency distribution of orbital indexes (ED/PrOL) in C. lemmingii and C. oretanum sp. nov.

Tabla 3.- Distribución de frequencias de los índices orbitales (ED/PrOL) en C. lemmingii y C. oretanum sp. nov.

\begin{tabular}{|c|c|c|c|c|c|c|c|c|}
\hline Species & $0.7-0.8$ & $0.8-0.9$ & $0.9-1$ & $1-1.1$ & $1.1-1.2$ & $1.2-1.3$ & $1.3-1.4$ & $1.4-1.5$ \\
\hline Ch. lemmingii & 10 & 28 & 24 & 7 & & & & \\
\hline Ch. oretanum sp. nov. & & & & 6 & 7 & 7 & 5 & 4 \\
\hline
\end{tabular}




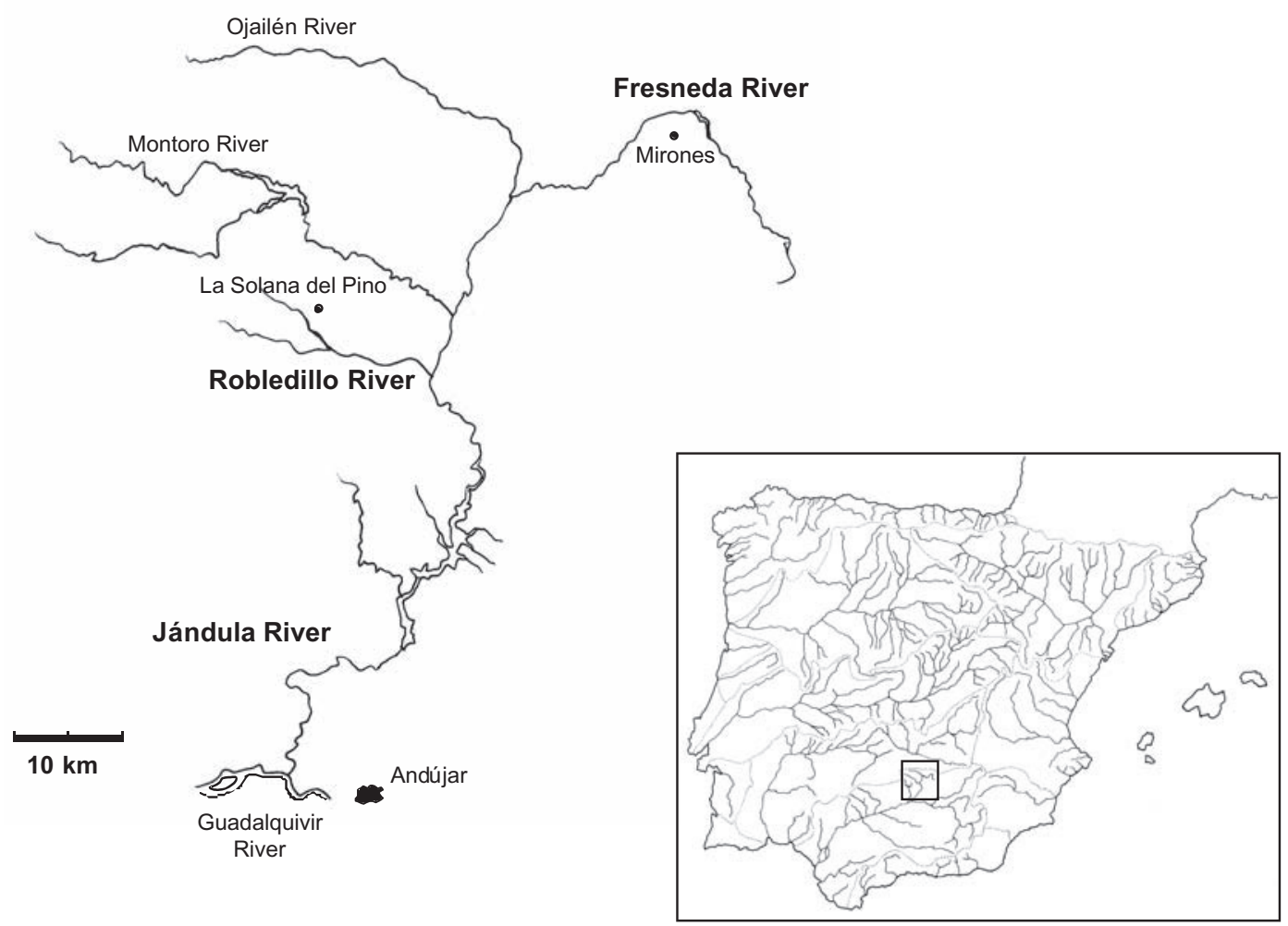

Fig. 3.- Distribution range of C. oretanum sp. nov.

Fig. 3.- Área de distribución de C. oretanum sp. nov.

warrants separating them into separate species. No available name can be assigned to the Robledillo population, and therefore, we have chosen to call this population Chondrostoma oretanum sp. nov.
Chondrostoma oretanum sp. nov. is differentiated from other populations of $C$. lemmingii by: 1) its more elongated body, 2) a long and narrow caudal peduncle and 3) its large eye diameter. The

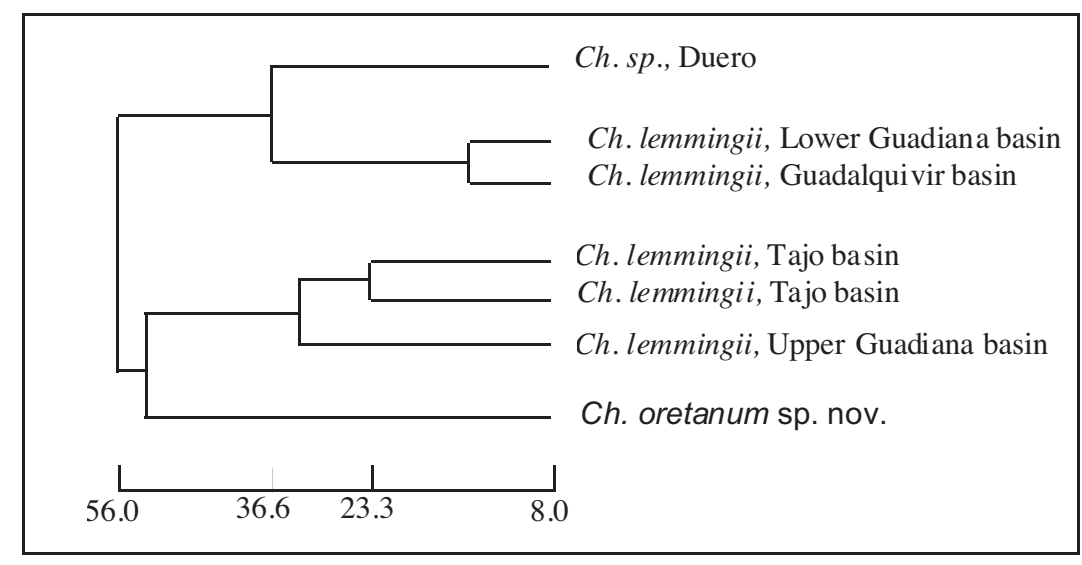

Fig. 4. - Cluster based on a similarity matrix of 21 morphometric variables among different $C$. lemmingii populations. The tree shows the high morphological differentiation of $C$. oretanum sp. nov. and C. sp from the Duero basin ( modified from Casado, 1995).

Fig. 4.- Agrupamiento basado en una matriz de similitud construida con 21 variables morfométricas tomadas de varias poblaciones de C. lemmingii. El árbol muestra la gran diferenciación morfológica de $C$. oretanum sp. nov. y $C$. $s p$ de la cuenca del Duero ( modificado de Casado, 1995). 
Table 4.- Summary of diagnostic characters of $C$. oretanum sp. nov based on a sample of 29 specimens. The C. lemmingii samlple is based on 69 individuals from the Guadiana basin. For gill rakers a sample of 28 individuals from Bembezar River in Guadalquivir basin was used.

Tabla 4.- Resumen de caracteres diagnósticos de C. oretanum sp. nov, sobre una muestra de 29 individuos. La muestra de $C$. lemmingii consiste en 69 individuos de la cuenca del Guadiana. Para la comparación de las branquiespinas se consideró la muestra de 28 individuos del río Bembézar en la cuenca del Guadalquivir.

\begin{tabular}{lcc}
\hline Characters & $\begin{array}{c}\text { C. lemmingii } \\
(\mathrm{n}=69)\end{array}$ & $\begin{array}{c}\text { C. oretanum sp. nov. } \\
(\mathrm{n}=29)\end{array}$ \\
\hline $\begin{array}{l}\text { Number of branched } \\
\text { rays on dorsal fin }\end{array}$ & 7 & $6-7$ \\
Number of branched & & \\
rays on dorsal fin & 7 & $6-7$ \\
Gill Rakers & $x=26.678(24-30)$ & $x=25.4(24-27)$ \\
Orbital index & $0.7-1$ & $1-1.5$ \\
Coronoid process & high and narrow & low and wide \\
Palatine process & toward behind & straight \\
Diagnostic Locus & $M D H-A * 100 / 105 / 110$ & $M D H-A * 80$ \\
\hline
\end{tabular}

eyes are placed in a very anterior position in the head. These characters were also found by Casado (1995) in a morphological study comprising several populations of $C$. lemmingii. Males from the Robledillo River population (females were not studied due to absence of material) were differentiated morphologically in a multivariate analysis of 22 morphometric variables using the Burnaby's method to correct for size effects (Fig. 4) (Casado, 1995). In addition, $C$. oretanum sp. nov. from the Robledillo River had significantly fewer gill rakers than did the $C$. lemmingii population from the Bembezar River $(\mathrm{n}=28)$. Both the aforementioned rivers are in the Guadalquivir basin (Table 4). Moreover, using molecular markers, $C$. oretanum sp. nov. showed a diagnostic locus $(M D H-A)$ and clear differences in allele frequencies at other loci (Carmona et al., 2000). There was a mean sequence divergence of $4.25 \%$ (uncorrected $p$ distance from the complete cytochrome $b$ nucleotide sequence) between $C$. oretanum sp. nov. and $C$. lemmingii (Carmona et al., 2000).

The genetic differentiation of $C$. oretanum sp. nov. respect to other $C$. lemmingii populations is similar to that found between other species of the genus Chondrostoma. For instance, one diagnostic locus separates $C$. polylepis from C. willkommii (Coelho, 1992; Coelho et al., 1997) and C. nasus (L. 1758) from C. vardarense Karaman, 1928
(Gollmann et al., 1997) whilst two diagnostic loci separate C. polylepis and C. willkommii from $C$. duriense (Coelho, 1992). Although the allele frequencies of C. lemmingii and C. arcasii differ greatly, no diagnostic loci were found for this species pair (Carmona et al., 2000).

\section{AKNOWLEDGEMENTS}

This study was financed by projects REM2001-0662/G10 and 07M/0109/02. We thank J. Cubo, I. Doadrio Jr., A. Doadrio, P. Garzón, M. González, F. Lerma and G. GonzálezCarmona for their assistance with field collections. We are grateful to M. García-París for his suggestions and improving some of the English text. Mr. James Watkins further revised the English text. The Regional Administration (Junta de Castilla-La Mancha) provided the necessary permits to collect the fish samples.

\section{References}

Carmona, J. A., Domínguez, J. \& Doadrio I., 2000. Congruence between allozyme and cytochrome $b$ gene sequence data in assessing genetic differentiation within the Iberian endemic Chondrostoma lemmingii (Pisces: Cyprinidae). Heredity, 84: 721-732.

Casado, M. P., 1995. Sistemática del género Rutilus Rafinesque, 1820 en la Peninsula Ibérica. Tesis Doctoral. Universidad Computense de Madrid. Madrid. 438 pp.

Coelho, M. M., 1992. Genetic differentiation of the Iberian cyprinids Chondrostoma polylepis Steind. 1865 and Chondrostoma willkommiii Steind. 1866. Archiv für Hydrobiologie, 125: 487-498.

Coelho, M. M., Alves, M. J., Collares-Pereira, M. J. \& Matson, R., 1997. Allozyme assessment of the phylogenetic relationships of the Iberian species Chondrostoma lemmingii and Ch. lusitanicum (Pisces: Cyprinidae). Folia Zoologica, 46(Suppl. 1): $15-26$.

DoADRIO, I., 1980. Descripción de un nuevo género y de una nueva especie Iberocypris palaciosi n. gen. n. sp. (Pisces, Cyprinidae). Doñana Acta Vertebrata, 7(1): 5-16.

DoAdrio, I., 2001. Atlas y Libro Rojo de los peces continentales de España. CSIC-MIMAN. Madrid. 363 pp.

DoADrIO, I. \& ElvirA, B., (in press). An overview of the genus Chondrostoma Agassiz, 1832 (Actinopterygii, Cyprinidae) in the Iberian Peninsula with a description of a new species. Folia Zoologica.

Gollmann, G., Bouvet, Y., Karakousis, Y. \& TRIANTAPHYLLIDIS, C., 1997. Genetic variability in Chondrostoma from Austrian, French and Greek 
rivers (Teleostei, Cyprinidae). Journal of Zoological Systematic and Evolutionary Research, 35: 165-169.

WASsERsug, R. J., 1976. A procedure for differential staining of cartilage and bone in whole formalinfixed. Stain Technology, 51(2): 131-134.

Zardoya, R. \& DoAdrio, I., 1998. Phylogenetic relationships of Iberian cyprinids: Systematic and biogeographical implications. Proceedings of the Royal Society of London, B265: 1365-1372.
ZARDOYA, R. \& DoAdrio, I., 1999. Molecular evidence on the evolutionary and biogeographical patterns of European cyprinids. Journal of Molecular Evolution, 49: 227-237.
Recibido, 7-VII-2003

Aceptado, 6-XI-2003 Publicado, 15-XII-2003 